\title{
THE ESTABLISHMENT OF A BALANCE BETWEEN PRIVATE INTERESTS OF THE AUTHORS AND PUBLIC INTERESTS OF THE SOCIETY IN THE DIGITAL AGE
}

\author{
Anastasiia Yefimenko \\ Postgraduate Student at the Department of Intellectual Property and Information Law, \\ Institute of Law, Taras Shevchenko National University of Kyiv, Ukraine \\ e-mail: yefimenkoanastasiia@gmail.com,orcid.org/0000-0003-4498-6927
}

\section{Summary}

The aim of this paper is to analyse the DSM Directive through the perspective of insurance the balance between private and public interests. The paper analyses how technological growth has led to the adoption of the DSM Directive, the goals set by the legislator and if they were met in the DSM Directive. The paper as well reviews key points of the DSM Directive and how it influences the interests of different parties in copyright. The article focuses on press publishers' rights, new exceptions and limitations and use of protected content by online content-sharing service providers, that were introduced by DSM Directive. The gaps of the DSM Directive are also reviewed in this article and how they impact the disbalance of interests in copyright. The article as well provides brief analysis how instruments brought up in DSM Directive may influence the copyright outside the EU. Methods used in this research: general scientific (analysis, induction, deduction), legal methods (legal comparation, formal legal method).

Keywords: copyright, digital age, interests, DSM Directive, online content-sharing service providers, exceptions and limitations, press publisher's rights.

DOI: https://doi.org/10.23856/4816

\section{Introduction}

In the context of constant scientific and technological progress and the inevitable globalisation, intellectual property is an important asset that needs proper legal regulation to stimulate market development and ensure the interests of all stakeholders. Copyright objects are potent drivers of both the economic and cultural development of society. In recent years, digital technologies have challenged copyright in various ways. The development of the information society has opened up a new way of using copyrighted works. It has led to the rapid growth of new business models, at the core of which are the objects of copyright. Nevertheless, on the other hand, this same development has opened the door to many new opportunities to infringe on the rights of exclusive rightsholders. However, the purpose of copyright remains the same: to protect the exclusive rights of rightsholders and to ensure a balance between their interests and the interests of society.

Unfortunately, the rapid development of the digital society does not match the pace of change in legal regulation, so legislators are critical to creating a flexible legal framework, both nationally and internationally, to ensure the rights and interests of all stakeholders, which will meet the rapid development of the information society. 
As rightly noted by Ms Trotska, scholars still ignore the issue of balancing public and private interests in copyright in the digital age (Trotska, 2019).

In the scope of this article, the tendencies to balance the interests of society and the private interests of rightsholders within the framework of public relations that arise between them regarding works protected under copyright in the digital environment will be considered. We will focus on the instruments that were introduced by Directive (EU) 2019/790 of the European Parliament and of the Council of 17 April 2019 on copyright and related rights in the Digital Single Market (hereinafter - Directive (EU) 2019/790 or DSM Directive), how they are implemented in the Member States and how they influence the interests of rightsholders and society.

\section{Instruments introduced in Directive (EU) 2019/790 for the establishment of a balance between private interests of the authors and public interests of the society in the digital age}

\subsection{New exceptions and limitations}

Two years ago, the Directive (EU) 2019/790 was adopted. As stated in recital 3 of Directive (EU) 2019/790, rapid technological development continues to change the way copyright objects are created, distributed and used. New business models and new actors continue to emerge. Relevant legislation must be sound for the future to restrict technological development, but the objectives and principles set out in the Community framework on copyright remain unchanged. However, legal uncertainty remains for both rightsholders and users regarding the specific use of works and other objects in the digital environment, including cross-border use. The Directive (EU) 2019/790 lays down rules for the adaptation of certain exceptions and limitations to copyright and related rights in the digital and cross-border environment (Directive (EU) 2019/790, 2019).

It is worth noting that the Directive (EU) 2019/790 has provoked much discussion from both within the EU Member States and interested market players.

Thus, Directive (EU) 2019/790 amended the system of exceptions and limitations on the use of copyrighted works without the consent of the author, which was introduced by Directive 2001/29/EC of the European Parliament and the Council of 22 May 2001 on the harmonisation of certain aspects of copyright and related rights in the information society (hereinafter - Directive 2001/29/EC or InfoSoc Directive). As is well known, the Directive, as a type of legislative activity in the Union, has a framework character and allows the Member States to implement the provisions introduced into national law. Therefore, if the exceptions and limitations under Directive 2001/29/EC) were optional (Directive 2001/29/EC, 2001), the new exceptions and limitations introduced by Directive (EU) 2019/790 are mandatory for implementation in national legislation by the Member States. Therefore, yes, Member States were required to implement the following exceptions and limitations:

1) Text and data mining for scientific research for reproductions and extractions made by research organisations and cultural heritage institutions (Art. 3 of Directive (EU) 2019/790);

2) Use of works and other subject-matters in digital and cross-border teaching activities (Art. 5 of Directive (EU) 2019/790);

3) Creation of copies of any works in any format or medium, for purposes of preservation of such works and to the extent necessary for such preservation (Art. 6 of Directive (EU) 2019/790) (Directive (EU) 2019/790, 2019).

As Mr Kapitsa duly noted it, it is not clear why the proposed list of exceptions and limitations was introduced in the new Directive (EU) 2019/790 as they could have been included by amending the relevant article of the Directive 2001/29/EC (Kapitsa, 2019:65). 
Mr Ferri has properly indicated that the new exceptions and limitations may be used only if they will meet the proportionality test designed in InfoSoc Directive, meaning that the exception/limitation does not conflict with the normal exploitation of the work. Therefore, it does not cause unreasonable prejudice to the right holder's legitimate interests (Ferri, 2020).

\subsection{Press publishers' rights}

One of the most controversial innovations introduced in the DSM Directive is Article 15, which protects the press publications concerning online uses. Under Art. 15, Member States shall provide publishers of press publications established in a Member State with the reproduction right and right of communication to the public for the online use of their press publications by information society service providers. In addition, if the other person intends to use the protected work, the publisher is entitled to bona fide compensation (Directive (EU) 2019/790, 2019).

The reasoning for such an amendment is based on how the digital economy has changed news consumption and how press publishers have issues licensing their rights to online news aggregators, media monitoring services, and search engines.

The rationale in the preamble to DSM Directive is that news is an important asset of democracy, and commercial news publishers have suffered financially from the development of the digital environment (Directive (EU) 2019/790, 2019).

Such regulation is not new for some EU Member States. In Germany, for example, a law was passed in 2013 that required aggregators of news and search engines to pay a fee for the use of excerpts from publishers' texts (Podszun, 2014).

Accordingly, to the Art. 2(4) of DSM Directive, press publication means a collection composed mainly of literary works of a journalistic nature, but which can also include other works or other subject matter, and which: constitutes an individual item within a periodical or regularly updated publication under a single title, such as a newspaper or a general or special interest magazine; has the purpose of providing the general public with information related to news or other topics; and is published in any media under the initiative, editorial responsibility and control of a service provider (Directive (EU) 2019/790, 2019).

It should be noted that Article 15 of the DSM Directive does not enshrine publishers' right to remuneration as absolute. Periodicals published for scientific or academic purposes, such as scientific journals, do not press publications for the Directive (EU) 2019/790. The term of protection is limited within two years from 1 January of the year following the publication date. Also, it is assumed that this right does not apply to individual words or very short excerpts from a printed publication; an exception is the "non-commercial use" of news publications. Also, publishers' rights do not apply to hyperlinks.

It shall be noted that press publishers' right regulation is not new for some Member States as in 2013 the relevant law was passed by Bundestag, under which Internet content providers to pay fees, collected by a central clearinghouse, to publishers for displaying their content: fees would have been levied for even short snippets of news made available by news aggregators and web search engines (Podszun, 2014). While the main aim of the press publishers' right regulation in Germany was to receive the remuneration from Google, the search engine has noted that Germany has failed to meet certain formalities in introducing such law, and the EU Commission had not been notified of the German technical regulation. In Case C-299/17, the Court of Justice of the European Union (CJEU) was asked by the regional court of Berlin to consider the enforceability of the German press publishers' right in light of the requirement to notify the European Commission of any draft technical regulation on services as foreseen in article 8(1) of 
the Directive 98/34/EC laying down a procedure for the provision of information in the field of technical standards and regulations. The CJEU found that the German press publishers' right is a rule specifically aimed at information society services (search engines) and a technical regulation which the EC should have been, but was not, notified of. Following the CJEU judgement, the German press publishers' rights became inapplicable and unenforceable $(C-299 / 17,2019)$.

The outcome of the Case C-299/17 took place in the timeframe of the acceptance of the DSM Directive. Therefore, after the implementation of the DSM Directive in the national legislations, the new requests may be raised by the CJEU as in our view, the content of Article 15 of the DSM Directive contains some vague points that will require assessment in the course of interpretation in national legislations of the Member States. While the goal of the legislators was to ensure the rights of the publishers, in the same type of uncertainty in the wordings chosen, will rather create more controversies.

\subsection{Use of protected content by online content-sharing service providers}

One of the most discussed provisions of the DSM Directive is the establishment of the liability of online content-sharing service providers (OCSSPs), i.e. "providers of an information society service of which the main or one of the main purposes is to store and give the public access to a large amount of copyright-protected works or other protected subject-matter uploaded by its users, which it organises and promotes for profit-making purposes" (Directive (EU) 2019/790, 2019). The introduced notion of OCSSPs tries to cover all varieties of service providers online and targets worldwide available platforms.

Under the Art. 17 of the DSM Directive, Member States shall provide that an OCSSP performs an act of communication to the public or an act of making available to the public when it gives the public access to copyright-protected works or other protected subject-matter uploaded by its users. Therefore, OCSSP shall obtain an authorisation from the rightsholders. Therefore, the OCSSP is directly liable for copyright infringements of their uses. Furthermore, the DSM Directive requests OCSSPs to establish "upload filters" to check the legality of the content uploaded by users (Directive (EU) 2019/790, 2019).

This article raised the wide range of public protests and discussions by academics.

The key issue raised is how such provision will co-exist with the fundamental human rights to freedom of expression and information.

In our opinion, Article 17 of the DSM Directive is an example of the introduction of disbalance between private interests of the rightsholders and public interests of the society. It creates unfair preponderance into rightsholders field, partially at the cost of the freedoms of others.

The Member States also raised this problem; namely, Poland has brought an action before CJEU requesting the annulment of parts of Article 17 DSM Directive because they violate users' fundamental right to freedom of expression and information in Case C-401/19.

Currently, the case is still in consideration of the CJEU, and as the final decision is yet to come, the opinion of Advocate General Saugmandsgaard Øe was delivered on July 15, 2021. AG has properly noted that the Court will have to determine whether such filtering is compatible with that freedom and to ensure that a 'fair balance' is maintained between, on the one hand, the interest of rightsholders in the effective protection of their intellectual property and, on the other, the interest of those users, and the general public, in the free flow of information online (ØE, 2021).

The AG holds the alternative opinion the Court should rule that that provision is valid and, consequently, dismiss the action brought by Poland. AG Øe finds that the limitation on the right to freedom of expression and information in Article 17 is justified and necessary for insurance 
of effective copyright protection. At the same time, he indicates that to avoid over-blocking, the safeguards for freedom of expression are necessary. AG has agreed that Poland has raised a valid point that Article 17 is a direct limitation of the freedom of expression. However, freedom of expression is not absolute, and limitations are permissible (ØE, 2021).

Ms Reda and her colleagues in their study on Article 17 have rightfully noted that it violates not also the freedoms of expression and information of the users, but the freedom to conduct a business of the OCSSP as basically puts on them the obligation to create recognition technologies, without the estimation of the costs and timeframe for such (Reda, Selinger, Servatius, 2020).

However, in his opinion, AG Øe presumably focuses on the freedom of expression and information and fails to assess the influence of Article 17 on other rights and freedoms.

AG Saugmandsgaard Øe's opinion will now be considered by the CJEU, who usually agrees with the Advocate-Generals' opinions.

\section{Conclusions}

With the acceptance of the DSM Directive, the new span in copyright regulation is not only within the European Union. It is fair to say that any major legislative initiatives in the EU, have if not direct, then consequential impact on the system of copyright worldwide.

It also shall be noted while the established forceful and justified goals, the reverberations of such cannot be duly estimated without giving proper time for the Member States to adjust and implement. Still, the DSM Directive needs to be discussed and observed for proper appraisal of possible issues that will arise in its implementation and how it strikes a balance between private and public interests in copyright.

1) Firstly, it is necessary to say that while one of the goals of the Directive (EU) 2019/790 is partial harmonisation of the EU copyright law in matters related to digital activities. However, considering that the national regulations vary from one Member State to another and that definitions and criteria established in the DSM Directive give the Member States the room for national legal creativity, the goal is to harmonise the EU's copyright, at least concerning digital activities will not be reached. It will likely lead to different implementation of vague definitions and disbalance how public and private interests contradict and vary from one Member State to another.

2) Secondly, while the rationale after the new exceptions and limitations was to provide that in the new age of technical means, copyrighted works may be freely used in scientific research and cultural preservation, the way how new exceptions and limitations were introduced and the scope of them, lacks the proper insurance of the public interests and seems just like vague attempt, rather than the considerable legal instrument.

3 ) It is interesting, the reasoning behind new press publishers' rights is to ensure the flow of news as a core element of democratic society, i.e. protection of public interests; however, at the same time covers the right of publishing houses for fair remuneration for the exploitation of their works in the digital medium.

While new press publishers' rights are a good example of coordination between public and private interests, the proposed scope of its protection lacks clarity and requires proper implementation.

4) While points made above superficially tried to ensure the public interests, Article 17 at the time strikes obvious disbalance in favour of the rightsholders. The wordings of Article 17 leave some margin of discretion for interpretation and implementation, which is, in our opinion, a dangerous way to handle the matter related directly to key fundamental rights. 
5) Finally, while one of the goals of the DSM Directive is to foster pluralism and endorse creativity and new models of copyright-driven business, it is clear that we will see clear contradictions and, as a result, disputes (nationally and in CJEU) between the fundamental rights and copyright. It shall be expected that CJEU will have to review the number of requests for interpretation and "fix" the gaps not filled by the legislators, and estimate the fair balance between private and public interests.

6) In addition, the impact of the legal doctrine of the European Union on the other jurisdictions, including the countries that entered into the association agreements with the EU, shall be noted. Namely, Ukraine, Moldova and Georgia, as countries that took the obligation to update national legislation according to the EU laws, shall consider how to consider DSM Directive in their national laws.

To sum up, it can be said that the review of the DSM Directive proves the complexity of the copyright and how it is necessary to considerer the number of contradicting interests and how in the course of law-making to ensure the system that will not sway the interests of one to the detriment of another in the long-term perspective. The DSM Directive must have been transposed into national law by 7 June 2021. However, the European Commission must review the Directive no sooner than 7 June 2026.

\section{References}

Directive 2001/29/EC of the European Parliament and of the Council of 22 May 2001 on the harmonisation of certain aspects of copyright and related rights in the information society, $O J$ L 167, 22.6.2001, p. 10-19.

Directive (EU) 2019/790 of the European Parliament and of the Council of 17 April 2019 on copyright and related rights in the Digital Single Market and amending Directives 96/9/EC and 2001/29/EC (Text with EEA relevance.), OJ L 130, 17.5.2019, p. 92-125.

Ferri, F. (2020). The dark side(s) of the EU Directive on copyright and related rights in the Digital Single Market. China-EU Law J. https://doi.org/10.1007/s12689-020-00089-5

Judgment of the Court (Fourth Chamber) of 12 September 2019 VG Media Gesellschaft zur Verwertung der Urheber- und Leistungsschutzrechte von Medienunternehmen mbH v Google $L L C, C-299 / 17$, OJ C 383 from 11.11.2019, p. 7.

Kapitsa Yu.M. (2019). Directiva 2019/790/ES pro avtorske parvo v yedynomu tsyfrovomu rynky ta pytannya adaptatsiyi zakonodavsta Ukrayiny [Directive 2019/790/EC on copyright in the Digital Single Market and the issue of adaptation of Ukrainian legislation] / Information and Law. 2019. No. 3(30). p. 65-77. http://ippi.org.ua/sites/default/files/10_14.pdf. [In Ukrainian] Podszun R. (2014). Google und das Leistungsschutzrecht für Presseverleger aus kartellrechtlicher Perspektive [Google and the IP Right for Publishers from a Competition Law Perspective] SSRN Electronic Journal. https://ssrn.com/abstract=2504153. [In German]

Reda J., Selinger J., Servatius M. (2020). Article 17 of the Directive on Copyright in the Digital Single Market: A Fundamental Rights Assessment. SSRN Electronic Journal. 10.2139/ ssrn.3732223.

Trotska V.M. (2019), Publichni interesy syspilstva = privatni interesy avtoriv. Chy mozhlyve dosyagnennya rivnovagy $v$ tsufrovy epohy? [Public interests of society = private interests of the authors. If the balance is possible?] / Theory and practice of intellectual property. 2019. No. 2.p. 5-16. http://nbuv.gov.ua/UJRN/Tpiv_2019_2_2. [In Ukrainian]

Opinion of Advocate General Saugmandsgaard Øe de ivivered on 15 July 2021 (1) Case C-401/19 Republic of Poland $v$ European Parliament, Council of the European Union https://eur-lex. europa.eu/legal-content/EN/TXT/?uri=CELEX\%3A62019CC0401. 